\title{
THE IMPACT OF THE EUROPEAN INTEGRATION PROCESSES ON THE ENTRY OF UKRAINE'S SMALL AGRICULTURAL PRODUCERS IN THE INTERNATIONAL LOGISTICS SYSTEMS
}

\author{
Kovalchuk Svitlana ${ }^{1}$ \\ Mazur Kateryna ${ }^{2}$ \\ Overkovska Tetiana ${ }^{3}$
}

DOI: https://doi.org/10.30525/978-9934-571-78-7_9

Abstract. The paper examines the importance of entry of small businesses in the international logistics systems. It is noted that the free trade zone between Ukraine and the EU has stimulated exports to many commodity producers, in particular small agricultural producers. The aim of the study is to examine specific features of the operation of logistics systems in agriculture under current conditions of integration in the international logistics systems. Methodology. A wide range of scientific methods has been used to achieve the goal of the scientific research, in particular, analysis, synthesis aimed to analyze the information and trends; induction and deduction with the purpose of data collection and formalization. The description and comparison were used to present the current state of logistics system development in Ukraine. Graphic methods were used to visualize the trends of the export of Ukraine's agricultural products to present the dynamics of cargo turnover in Ukraine.The paper outlines the main trends of the logistics systems development in the agrarian sector. It analyzes the geographic structure and mode of transport to the countries of export of transportations of Ukraine and shipping of cargoes (grains and products of grinding) by different kinds of transport. It is emphasized that stability of the international logistics system is provided by the linking elements between the re-gion's economy, small businesses and consumers. The authors make emphasis on the Logistics Performance Index (LPI) and possibilities of its improvement through the development of monofunctional stations,

\footnotetext{
${ }^{1}$ Candidate of Economic Sciences, Associate Professor,

Vinnytsia National Agrarian University, Ukraine

${ }^{2}$ Candidate of Economic Sciences, Associate Professor,

Vinnytsia National Agrarian University, Ukraine

${ }^{3}$ Candidate of Law Sciences, Associate Professor,

Vinnytsia National Agrarian University, Ukraine
} 


\section{Chapter «Economic sciences»}

which include services of intermodal container transportation, ensure environmentally friendly transportation and accessibility, and improve the quality of transport services. Insufficient development of modern transport and logistics technologies, multimodal transport systems and powerful multimodal transit operators restraints the lack of the extensive network of cargo customs systems and logistics centers in the area of their attraction to large transport units, significantly reduces possibilities of fulfillment of the potential of the national transport system, reduces its competitiveness compared to the countries of the Eastern Europe and the Baltic States that are more developed in this field. Is the use of the offered chart of activity of o monofunctional units for rural territories will be instrumental in more effective including of shallow agricultural producers to the international logistic systems.

\section{Introduction}

Agricultural production is an important industry for Ukraine, which ensures food security as well as economic and national security. Sustainable development of the agricultural sector is declared as a key to economic growth and efficiency.

According to the Strategy for the Agricultural Sector Development 2020 , one of the strategic goals of the agrarian sector development is to ensure predictability of the development and long-term sustainability of the agrarian sector through the development of various business forms as well as the expansion of Ukraine's engagement in supplying the world market with agricultural products. It should be noted that the support of development of small and medium-sized agricultural producers, including family farms, is one of the directions of the state agrarian policy strategy as the world counts on small and medium-sized businesses. Entering the world agricultural market by small commodity producers should facilitate the improvement of forms and methods of the state support as well as the development of effective instruments for the implementation of such support, including the fulfillment of forwarding services in the field of supply of produced agricultural products [14].

Consequently, one of the main tasks of the agrarian policy of Ukraine is the comprehensive promotion of the development of small business forms, which cannot be achieved without the use of an extensive system of instruments of direct and indirect influence. Logistics holds an important 
position among such tools. The development of modern logistics systems involves active engagement of the agricultural producers with welldeveloped infrastructure in rural areas.

The aim of the study is to examine specific features of the operation of logistics systems in agriculture under current conditions of integration in the international logistics systems.

According to E. Fedoruk [2], the increase in turnover of assets of agricultural producers is focused on controlling the terms of receipt and transfer of goods through the supply chain in order to reduce the idle time, long storage and other temporary losses, and it also requires a review of working conditions with counteragents in order to optimize the amount of current capital invested in the assets of a business entity.

The strategy of "optimizing the sales chain", which is the most appropriate for agrarians, involves reducing the number of intermediaries in the domestic market due to independent supplies to traders or external counterparts [2, p. 223-229].

The use of logistics tools in the activities of agribusinesses reveals a significant potential for increasing economic efficiency of their activities due to lower costs, as it allows, on the one hand, to regulate the processes of physical movement of goods, and, on the other hand, it directs commodity producers to the formation of optimal channels of flow of the finished agricultural products [11, p. 237-242].

Optimization of the inventory levels in the warehouses and minimization of illiquid commodities are closely connected with the optimization of supply, distribution and inventory. The methodology is based on identifying and eliminating the causes of losses, changing the business schemes (for example, implementing a system of Vendor Managed Inventory), analysis of the warehousing system and inventory management [2].

Investigating the current state of entry of the national agricultural producers into international logistics systems, N. Khvyschun [5] argues:

There can be observed inefficient movement of regional flows, which is primarily caused by the undeveloped logistics infrastructure of the regions. Thus, low quality of motor roads, lack of investments in modernization of ports and airports, high depreciation of fixed assets of transport enterprises, lack of integrated regional logistics centers lead to an increase in the cost of resources and time associated with the use of regional flows from agricultural producers to con-sumers (p. 3). 


\section{Chapter «Economic sciences»}

In addition, today a major problem for the development of logistics systems in Ukraine is insufficient development of the theoretical aspects of this issue. A comparative analysis of methods for assessing the logistic potential of a system of different hierarchical levels (micro, meso-, macro) leads to conclusion that none of the current methods of assessing the logistics potential of the region can be considered universal as they include a large number of indicators that aggravate the analysis and only some of them can be applied under conditions of the Ukrainian economy. In addition, only some of the studies are comprehensive and can fully reflect the real state of the regions [5, p. 1-6].

The world community uses the Logistics Performance Index (LPI), which has been calculated by the World Bank since 2007 to measure the performance of the international supply chains. It takes into account infrastructure, legal framework, policy measures, geographic location and political economy (LPI, 2017).

The LPI takes into consideration the level of cooperation and establishment of relationships of private enterprises and the state as a whole, and it also allows us to assess the potential of their further development [3, p. 223-229].

Nowadays, LPI is used not only as a rating comparison of states, e.g. in Indonesia LPI is officially used to estimate the results of activities of the Ministry of Trade, while Asia-Pacific Economic Cooperation uses LPI to determine the impact on the development of interrelations in the supply chain; the European Commission uses LPI when forming the European system of evaluation of the transport efficiency. However, according to estimates by experts, the Ukrainian logistics system is constantly progressing, which is shown by the dynamics of the national logistics performance index. Thus, Ukraine ranked 73 among 150 world countries (LPI - 2.55) in the LPI rate of 2007; in 2014 the LPI was 2.98, which let Ukraine take 61st position among Argentina (2.99) and Egypt (2.97) among 160 countries of the world. But in 2016, Ukraine ranked 80th (2.74), having actually worsened the quality of the entire infrastructure.

Scientists have reported that LPI enables to identify the states that are taking the lead or leaving behind in the logistics development. This index takes into account the degree of cooperation and relationship between private enterprises (business entities) and state in general, and it also enables to evaluate the potential of their further development [10, p. 34-37]. 
Therefore, a priority direction of the agrarian sector development in Ukraine, in particular sustainable development of rural territories, is impossible without the logistics systems integrated into the world economy.

\section{Literature review}

Modern researchers pay much attention to searching for the new ways for enhancing the efficiency in different sectors of the economy in general and in agriculture as well. One of the ways that can provide higher efficiency is modernization of logistics and food supply chain.

The study by Vorotnikov et al. (2017) found the following:

Solving agricultural problems is possible only with the use of modern trends, providing innovative approaches, taking into account the improvement of the organizational-economic mechanism. It is obvious that these trends must meet the principles of the systems, and take into account existing restrictions. In our opinion, one of the most effective tools is logistics, which is very effective in different sectors of economics (p. 24).

A similar opinion is presented in the research by Shumin Luo and Hua Xuan. The article underlines the necessity of the agricultural logistics industry development in the conditions of economic globalization. The scientists analyze agricultural product logistics distribution system, general situation of enterprises, the problems of logistics and distribution of agricultural products and make some suggestion to solve the problems [7].

Further researches are presented by Jun Li, Hongmei Gao and Yuchuan Liu, who studied one-stop logistics management requirements based on the project experience in Tianjin. The results of their investigation can be fruitful for further design of the fresh agricultural products logistics information management systems [6].

Moreover, fundamental investigations of the logistics system development are provided by the economists from China and Brasil. Zhao Yingxia \& Guo Xiangyu presented the article that analyzes "quick development of the Chinese agricultural product logistics, and proposes countermeasures aiming at the existing questions of the Chinese agricultural product logistics development" [20] and "characteristics of the Brazilian cargo transportation matrix, detailing some aspects of the country's agricultural freight market" are presented in the investigation done by José Vicente Caixeta-Filho [1].

Much attention is paid to the logistics system development and agricultural logistics in the works of domestic researches. The importance 
of the logistics improvement is mentioned in O. Volnova's research that claims that "the implementation of the logistic approaches to entrepreneurial activity becomes very relevant in the current conditions for the transition to market relations, in particular, it concerns agricultural production. This is due to the processes of integration, intensification and expansion of commodity-money relations, interconnected branches, including industrial infrastructure" [17, p. 161-164]. Moreover, we agree with O. Shmatock that agricultural logistics is one of the developing sectors. Today, in Ukraine the state of agrarian logistics is at the stage of its development, although now it is possible to distinguish several enterprises that are recognized in the international market. But for the construction of a strong system of agro-logistics, a search for the ways of integration of the Ukrainian system of agrarian logistics into the world system of trade logistics is of great relevance [11, p. 237-242].

In addition, the issues of the use of logistics theory and tools have been investigated by J.J. Bauersox, D. Wardlove, D. Wood, J. Johnson, D.J. Klos, P. Merfimol, S. Maslak [8], O. Maslak [9], V. Yefanov [19], M. Lynders, H. Fyron, D. Stoke, D. Lambert, B. Anikin, A. Hadzhynskyi, S. Molnar [10], Y. Nerush, V. Serheev, E. Fedoruk [2].

Summarizing the results of the previous studies, it should be noted that functioning of logistics systems, in particular the development of the infrastructure in the rural areas, is being formed. A vast majority of research papers study logistics in the context of the development of industries, and only some scientists have examined logistics in the agrarian sector. Considering specific features of the agrarian sector development in Ukraine, in particular a great number of small business forms, which have a low level of competitiveness compared to large integration groups, it is expedient to investigate the prospects and directions of the development of logistics systems of the agrarian sector in the context of preserving rural areas.

\section{Results and discussion}

Transformations of the agrarian sector into European space, adaptation to the requirements of the Common Agricultural Policy of EU, active development of the integration groups, and the need to support small agricultural producers to integrate them into the production and supply chain with access to the inter-national markets are the main features of the present time. 
Under the influence of globalization processes in the world economy accompanied by the intensive development of transport infrastructure of the countries, the competition is being intensified, new markets are being searched for, which leads to formation of special macrosystems of the logistic nature. At the same time, the processes of the European integration are involving the agrarian sector more and more with the need to enter the international logistics systems. Aimed to determinate the external factors of the small rural business development in Ukraine we can use PESTLE-analysis. It helps to determinate political, economic, social, technological, legal and environmental factors that are influence on the enterprises (Table 1).

However, the phenomenon of the development of logistics systems in the agrarian sector of Ukraine has become widespread in the last decade due to active foundation of large integration groups (agroholdings) and development of their infrastructure. As a result of the active operation of integration groups, the inflow of foreign investments into agriculture has accelerated the development of logistics systems.

Along with this, the main feature of globalization processes in the agrarian sector is the co-operation of small businesses and public production. Processing and marketing of products are supplemented by associations in the field of production, although in most countries, dominant positions are hold by cooperation that engages both agriculture and related industries.

According to Hutorov, Prozorova, and Prozorov [4], the characteristic feature of the European integration processes in the agricultural sector is the development of the international logistics systems in compliance with the basic rules of logistics, i.e. "7R": $1 \mathrm{R}$ - right product; $2 \mathrm{R}$ - right quality; $3 \mathrm{R}$ - right quantity; $4 \mathrm{R}$ - right time; $5 \mathrm{R}$ - right place; $6 \mathrm{R}$ - right customer; $7 \mathrm{R}$ - right cost.

Entry of agricultural commodity producers into the international transport and logistics systems greatly increases labor productivity. According to expert estimates, half (2.5-4.5\%) of the overall annual increase in labor productivity (5-9\%) is achieved due to the distribution of logistics. According to the estimates of US experts, $1 \%$ reduction of logistics costs is equivalent to almost $10 \%$ increase in sales. It should be noted that Western companies having less than $10 \%$ profitability are willing to spend millions to reduce logistics costs by a tenth of a percent [4].

Analysis of the logistic tools of agricultural enterprises [19, pp. 94-99] allows us to identify the main trends in the development of logistics systems in the agrarian sector: 
PESTLE-Analysis of the Small Rural Business Environment in Ukraine

\begin{tabular}{|c|c|c|c|}
\hline Political & $\mathbf{P}$ & Economic & $\mathbf{E}$ \\
\hline \multicolumn{2}{|l|}{$\begin{array}{l}\text { 1. Unfavourable investment climate } \\
\text { conditioned by political instability; } \\
\text { 2. Military conflict in the East of Ukraine; } \\
\text { 3. Lack of connection between government, } \\
\text { re-search and the real sector of the economy; } \\
\text { 4. The unpredictability of the results of the } \\
\text { 2019 presidential election } \\
\text { 5. Recognition of the priority of the } \\
\text { development of the agrarian sector and } \\
\text { innovation at the state level; } \\
\text { 6. Imperfect customs policy of the state; } \\
\text { 7. Imperfect tax policy. }\end{array}$} & \multicolumn{2}{|c|}{$\begin{array}{l}\text { 1. Activation of foreign economic } \\
\text { activity in the region; } \\
\text { 2. High inflation rate; } \\
\text { 3. A significant share of the shadow } \\
\text { food market; } \\
\text { 4. Fluctuations in fuel prices; } \\
\text { 5. The presence of large agrarian } \\
\text { structures that can become the centre } \\
\text { of investment attractiveness and } \\
\text { production activity; } \\
6 \text {. Gradual economic recovery; slight } \\
\text { but sta-ble GDP growth. }\end{array}$} \\
\hline Social & S & Techn & $\mathbf{T}$ \\
\hline \multicolumn{2}{|l|}{$\begin{array}{l}\text { 1. Modern innovative systems of motivation } \\
\text { of agricultural producers and workers; } \\
\text { 2. Aging of the nation, increasing number of } \\
\text { el-derly people; } \\
\text { 3. Urbanization, rural development problems; } \\
\text { 4. The level of wages in agriculture is one of } \\
\text { the lowest among the branches of the national } \\
\text { econ-omy. }\end{array}$} & \multicolumn{2}{|c|}{$\begin{array}{l}\text { 1. High degree of wear of main } \\
\text { production assets, the need to } \\
\text { accelerate their upgrade. } \\
\text { 2. Use of innovative technologies } \\
\text { in the transportation of agrarian } \\
\text { products. } \\
\text { 3. Automation and mechanization of } \\
\text { all pro-duction processes; } \\
\text { 4. Rapid pace of development of } \\
\text { scientific and technological progress; } \\
\text { new technology and techniques. }\end{array}$} \\
\hline Legal & L & Ecological & $\mathbf{E}$ \\
\hline \multicolumn{2}{|l|}{$\begin{array}{l}\text { 1. Possibilities for use by small agricultural } \\
\text { en-terprises of INCOTERMS international } \\
\text { rules; } \\
\text { 2. European integration strategy of Ukraine } \\
\text { aimed at accelerating integration processes } \\
\text { and economic development; } \\
\text { 3. Impact on the small agricultural } \\
\text { commodity producers in the Free Trade Zone } \\
\text { with the EU; } \\
\text { 4. Increasing the efficiency of public } \\
\text { administra-tion in the transport sector. }\end{array}$} & \multicolumn{2}{|c|}{$\begin{array}{l}\text { 1. Prospects for the formation } \\
\text { of a balanced system of nature } \\
\text { management in agriculture; } \\
\text { 2. Ensuring the wide introduction } \\
\text { of the lat-est ecologically balanced } \\
\text { technologies in agriculture; } \\
\text { 3. Support for the development of } \\
\text { biological agriculture; } \\
\text { 4. Biofuels production development. }\end{array}$} \\
\hline
\end{tabular}


- fundamental changes in the philosophy of inventory;

- expansion of the assortment of the product types;

- computerization of the agricultural activity of agrarian enterprises.

- development of a retail network with very complex logistics systems. In addition to the centers of mass trade, there have appeared networks of large specialized stores, which flourish thanks to well-developed logistics systems;

- expansion of the range of suggested logistics services;

- outsourcing - transfer of functions of control over the distribution of finished products from manufacturers to specialized enterprises. This allows them, firstly, to use the greater experience of specialized logistics enterprises in the distribution of products, and secondly, to focus mainly on their main activities such as production, development and promotion of their products, and, thirdly, to reduce unprofitable costs;

- reduction of the number of suppliers and formation of a long-term cooperation with logistics enterprises. In the past, enterprises had a large number of competing suppliers, which helped to make beneficial agreements in order to improve the logistics management practices [19, p. 94-99].

Implementation of the Association Agreement provides some opportunities for agriculture in the mutual trade of Ukraine and the EU. In the European integration conditions, for increasing competitiveness, the results of business activates of agricultural producers are largely dependent on lower costs and higher profits. The cost of production has a decisive influence on the price of the resource, and the amount of revenues is affected by the price of sales as well as the warehouse, transport and logistics costs. As a consequence of the effect of all factors, the final result of agricultural production is the successful organization of logistics activities and the position of the agricultural producer in the international transport and logistics system. So, establishment of the logistics systems at the enterprises can ensure successful agricultural activity.

Due to analysis of the World Bank's statistical data, the geographic structure by mode of transport and countries of export has been developed (Figure 1).

In modern conditions logistics enterprises are much more engaged in the management of all processes in the supply chain, and enterpriseconsumers more often familiarize them with their long-term goal for the joint development of mutually acceptable solutions. Consumers value 


\section{Chapter «Economic sciences»}

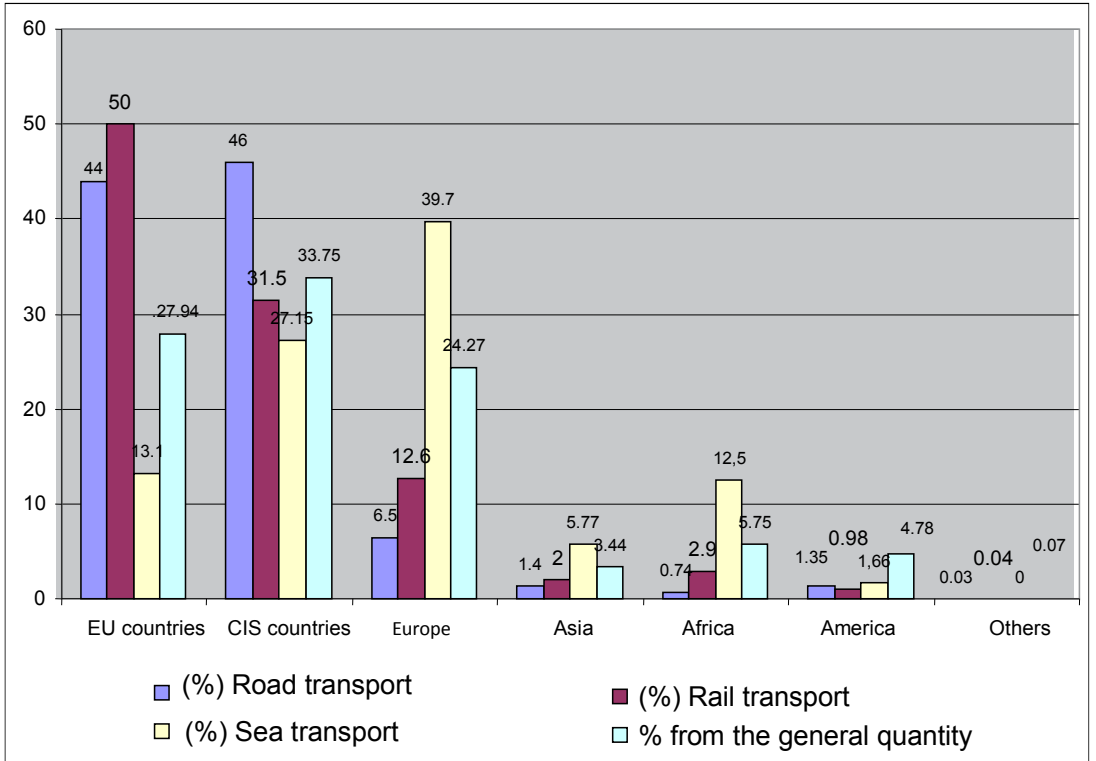

Figure 1. Geographical structure of the Ukrainian export by the mode of transport

Source: compiled by the authors

their time and trust much more the professionals in logistics with whom they cooperate. They seek to limit their number, but develop long-term cooperation with those they have chosen as partners.

It is known that the main feature of the agricultural sector is seasonal production. Statistics shows that grain and oil crops are the main products transported by the agricultural producers (Table 1).

So, over $80 \%$ of the gross grain output is sold by farmers in JulyDecember. The same was with oilseeds. Almost $80 \%$ of commercial seed was sold in the first half of the season. This is due to the fact that farmers have significant internal and external financial obligations, which they try to reduce or eliminate through the revenues from the harvest sale. Agrarian enterprises independently define approaches to the sale of products, among them the most widely distributed sales strategies are the optimization of the sales chain, expectation of the attractive value, price comparison [8, p. 22-27]. 
Road transportation of agricultural products according to nomenclature of cargoes in 2016-2017, thousand tons

\begin{tabular}{|c|c|c|c|c|}
\hline & $\begin{array}{c}\text { Total cargo } \\
\text { transported, } \\
2016\end{array}$ & $\begin{array}{c}\text { Among } \\
\text { them in the } \\
\text { international } \\
\text { transportation, } \\
2016\end{array}$ & $\begin{array}{c}\text { Total cargo } \\
\text { transported, } \\
2017\end{array}$ & $\begin{array}{c}\text { Among } \\
\text { them in the } \\
\text { international } \\
\text { transportation, } \\
2017\end{array}$ \\
\hline Total & 123196.10 & 6581.92 & 126471.96 & 7055.62 \\
\hline $\begin{array}{l}\text { products of } \\
\text { agriculture, hunting } \\
\text { and forestry; fish } \\
\text { and other fishery } \\
\text { products } \\
\end{array}$ & 15739.81 & 479.08 & 17628.50 & 531.76 \\
\hline cereals & 11966.57 & 118.66 & 13147.91 & 115.76 \\
\hline potato & 125.41 & 1.82 & 127.22 & 1.80 \\
\hline sugar beet & 552.01 & 0.31 & 790.42 & 0.09 \\
\hline $\begin{array}{l}\text { other fresh } \\
\text { vegetables and } \\
\text { fruits }\end{array}$ & 317.36 & 76.81 & 366.45 & 107.88 \\
\hline $\begin{array}{l}\text { forest or timber } \\
\text { products }\end{array}$ & 749.39 & 188.05 & 725.95 & 156.28 \\
\hline $\begin{array}{l}\text { live plants and } \\
\text { flowers }\end{array}$ & 11.15 & 4.15 & 15.57 & 4.78 \\
\hline $\begin{array}{l}\text { other products of } \\
\text { plant origin }\end{array}$ & 1626.44 & 65.92 & 1935.37 & 106.75 \\
\hline Live animals & 35.78 & 1.26 & 6.96 & 1.40 \\
\hline $\begin{array}{l}\text { raw cow, sheep and } \\
\text { goat milk }\end{array}$ & 271.49 & - & 399.34 & 0.08 \\
\hline $\begin{array}{l}\text { other raw materials } \\
\text { of animal origin }\end{array}$ & 30.67 & 10.99 & 49.77 & 11.58 \\
\hline $\begin{array}{l}\text { fish and other } \\
\text { fishery products }\end{array}$ & 53.54 & 11.11 & 63.54 & 25.36 \\
\hline
\end{tabular}

Source: State Statistics Committee, 2017

The free trade area has inspired integration with the European legislation and has become an additional opportunity for export to many producers. New companies that have not previously been exporting to the EU, including small and medium-sized enterprises, have gradually started to emerge or at least have shown interest in the EU market. 


\section{Value of method of transporting}

Agrarians use their private transport for internal shipping, while international logistics systems are used for the international transportation. However, small and medium-sized enterprises sale grain to commercial structures limiting the distances for the product transportation minimum, including self-delivery from the producer's warehouse. Road transport is mostly used for these purposes, while rail transport is used less often. The choice of the mode of transport depends on the type, volume, and distance of cargo transportation [8, p. 22-27].

The dynamics of cargo transportation in the agrarian sector of Ukraine in the context of using different modes of transport is presented in the tables. Table 2 shows the dynamics of sea transportation of agricultural products.

According to Malysh [8, p. 22-27], in his foreign economic transactions an agrarian producer meets the requirements for the transportation of products specified by the international rules of INCOTERMS. According to these rules, the supply of goods on the basis of EXW (ex warehouse) and CPT (carriage paid to, i.e. delivery to an agreed place is paid) is more common for internal transactions, while export of goods requires other basic conditions. Thus, according to foreign trade agreements, the most frequent carriage on the basis of FCA (free carrier), which provides appropriate preparation of the products and documents for shipment and DDU (delivery without payment of customs duties) and takes into account

Table 2

Sea transportation of cargo in 2016-2017*

\begin{tabular}{|c|c|c|c|c|c|c|}
\hline & \multirow{2}{*}{$\begin{array}{c}\text { Total cargo } \\
\text { transported } \\
\text { in 2016, } \\
\text { (thou-sand } \\
\text { tons) }\end{array}$} & \multicolumn{2}{|c|}{$\begin{array}{c}\text { Including } \\
\text { transportation in } \\
\text { 2016, thousand tons }\end{array}$} & \multirow{2}{*}{$\begin{array}{c}\text { Total cargo } \\
\text { transported } \\
\text { in 2017, } \\
\text { thousand } \\
\text { tons }\end{array}$} & \multicolumn{2}{|c|}{$\begin{array}{c}\text { Including } \\
\text { transporting in 2017 } \\
\text { (thousand tons) } \\
\end{array}$} \\
\hline & & domestic & foreign & & domestic & foreign \\
\hline Total & 3032.5 & 1130.1 & 1902.4 & 2253.1 & 845.3 & 1407.8 \\
\hline $\begin{array}{l}\text { Grain and } \\
\text { milled } \\
\text { products }\end{array}$ & 99.9 & - & 99.9 & 200.0 & 132.1 & 67.9 \\
\hline $\begin{array}{l}\text { Among } \\
\text { them grain }\end{array}$ & 99.9 & - & 99.9 & 178.3 & 110.4 & 67.9 \\
\hline
\end{tabular}

Source: State Statistics Committee, 2017 
the seller's costs for the product transportation to the destination. For the international railway transportation the basic conditions of DAF (delivery to the border) are mainly used, according to which the seller pays the cost of goods transportation to the customs border. Sea transportation is mainly limited by the conditions of FOB (free on board) with the indication of the port of shipment, which includes the seller's expenses on the vessel's freight. Therefore, the basis of the product supply affects additional costs, and therefore the product price. In general, when applying this strategy, farmers have additional costs for product sales - from 3 to $10 \%$ of production costs, and they have an opportunity to increase revenues from product sales from 5 to $10 \%$ [8, p. 22-27].

The dynamics of transportation of agricultural products in Ukraine is presented in Table 3.

According to the data provided, there can be observed $11.8 \%$ increase in the volumes of transportation of grain and grain products in 2017 compared to 2016 and $10.8 \%$ increase in 2016 compared to 2015. Such tendencies reveal a positive dynamics in the development of Ukraine's transportation and logistics system.

The total cargo turnover of Ukraine, in the section of rail, road, water, pipeline and air transport is presented in Table 4.

Statistical data (Table 2, 3, 4) prove that the transport system of Ukraine used by agricultural producers does not work at maximum capacity, i.e. current transit potential of Ukraine is used by $70 \%$, and public transport (without pipelines) is used only by 50\%, that is about 5-7 billion US dollars in the cash equivalent.

Table 3

Railway transportation of cargoes in 2016-2017 1,2

\begin{tabular}{|l|c|c|c|c|}
\hline & $\begin{array}{c}\text { Transported, } \\
\text { mln t 2016 }\end{array}$ & $\begin{array}{c}\mathbf{2 0 1 6} \\
\text { \% by 2015 }\end{array}$ & $\begin{array}{c}\text { Transported, } \\
\text { mln t 2017 }\end{array}$ & $\begin{array}{c}\mathbf{2 0 1 7}, \\
\text { \% by 2016 }\end{array}$ \\
\hline $\begin{array}{l}\text { Cargoes } \\
\text { transported }\end{array}$ & 344.1 & 98.3 & 339.5 & 98.9 \\
\hline $\begin{array}{l}\text { grains and } \\
\text { milled products }\end{array}$ & 31.9 & 110.8 & 35.7 & 111.8 \\
\hline
\end{tabular}

${ }^{1}$ Temporarily occupied territory of the Autonomous Republic of Crimea, the city of Sevastopol and parts of the zone of the anti-terrorist operation are not included

${ }^{2}$ According to the operational data of PJSC "Ukrainian Railways"1

Source: State Statistics Committee, 2017 
Cargo turnover and volumes of cargo transportation in 2017,

\begin{tabular}{|l|c|c|c|c|}
\hline \multirow{2}{*}{} & \multicolumn{2}{|c|}{ Cargo turnover } & \multicolumn{2}{c|}{ Volume of transported cargoes } \\
\cline { 2 - 5 } & $\mathbf{m l n} \mathbf{~ t ~ k m}$ & $\mathbf{\%}$ by 2016 & mln t & \% by 2016 \\
\hline Transport & $\mathbf{3 4 3 0 5 7 . 1}$ & $\mathbf{1 0 5 . 8}$ & $\mathbf{6 3 5 . 9}$ & $\mathbf{1 0 1 . 8}$ \\
\hline rail2 & 191914.1 & 102.3 & 339.5 & 98.9 \\
\hline road & 41178.8 & 108.4 & 175.6 & 104.7 \\
\hline water & 4257.1 & 106.3 & 5.9 & 88.1 \\
\hline pipeline & 105434.4 & 111.7 & 114.8 & 107.6 \\
\hline air & 272.7 & 120.5 & 0.1 & 110.5 \\
\hline
\end{tabular}

${ }^{1}$ Temporarily occupied territory of the Autonomous Republic of Crimea, the city of Sevastopol and parts of the zone of the anti-terrorist operation are not included ${ }^{2}$ According to the operational data of PJSC "Ukrainian Railways"

Source: State Statistics Committee, 2017

Among the European countries, Ukraine holds the highest transit rate of 3.75. It is achieved due to a powerful transit system, which can transfer about 200 million tons of goods through its pipelines, and more than 60-70 million tons of goods through its railways, inland waterways and motor transport [2, p. 110-118].

\section{Factors of influence are on functioning of monofunctional units}

Thus, the growth of the competitiveness of domestic agricultural products in the foreign markets determines the provision of optimal transport services and organization of transportation of cargoes by various transport as well as maintenance and provision of the necessary equipment in the ports, warehouses at the railway stations, terminals or other facilities for the timely shipment of exported agricultural products.

Since the choice of the mode of transport and, therefore, transportation costs are affected by such factors as the distance between the producer of agricultural products and its consumer, transportation route, duration and cost of transportation services, mode of transport and its ability to preserve the quality of agricultural products, the Transport Strategy of Ukraine 2020 approved by the Cabinet of Ministers of Ukraine on October 20, 2010, No. 2174-p defined key directions for improving transportation and expedition services, including small business forms. They are as follows: 1) development of the transport infrastructure through the development of a network of logistic centers; 2) improvement of the investment climate 
by the development of the state and private partnership; 3) availability and improvement of the quality of transport services by the development and implementation of the state social standards and regulations of the transport services; providing fast cargo delivery in accordance with the world experience; optimization of routes of the air, road, rail, and water transport; 4) integration of the domestic transport system into the European and international transport systems through unification of the requirements for the carrier; maintenance of interoperability of transport networks of Ukraine and near-by states; simplification of the customs procedure for goods and reasonable reduction of the time required for conducting control procedures at the customs stations that should operate in accordance with the European regulations; 5) increasing the efficiency of public administration in the transport sector through coordination of the work of various kinds of transport [13].

Coordination of the operation of enterprises of different types of transport while transporting goods, agricultural products is carried out on the basis of contractual relations, i.e. by concluding nodal agreements in accordance with the requirements of Article 39 of the Law of Ukraine "On the Transport" (amended on December 28, 2015, No. 901-19).

It should be noted that the factors of long-term sustainability of the agrarian sector in terms of economic and social indicators are the economic, organizational and sectoral structures. Today, $43 \%$ of the gross agricultural output is produced by the citizens, on the plots of the private farms. As a rule, these products are not export-oriented, the logistics of their storage is insufficient and their production requires significant labor costs, namely: fruit and berries $-80.9 \%$, potatoes $-97.8 \%$, vegetables $-86.1 \%$, milk $-74.9 \%$ of production of the corresponding product [15].

Further effective entry of small business forms of agricultural producers into the international logistics systems can be provided by the fulfillment of such basic services as intermodal container transportation by the operators of the road, rail and, in some cases, sea transport; reliable and inexpensive container and ro-ro shipping through the Black Sea; road and railway container transportations through longer major domestic routes; tools for multimodal use of inland waterways for agricultural cargoes; availability of logistic centers (monofunctional units) and high-quality warehouse capacity.

In our opinion, effective intermodal transportation is possible under proper functioning of monofunctional units (Fig. 2). The main factors of 


\section{Chapter «Economic sciences»}

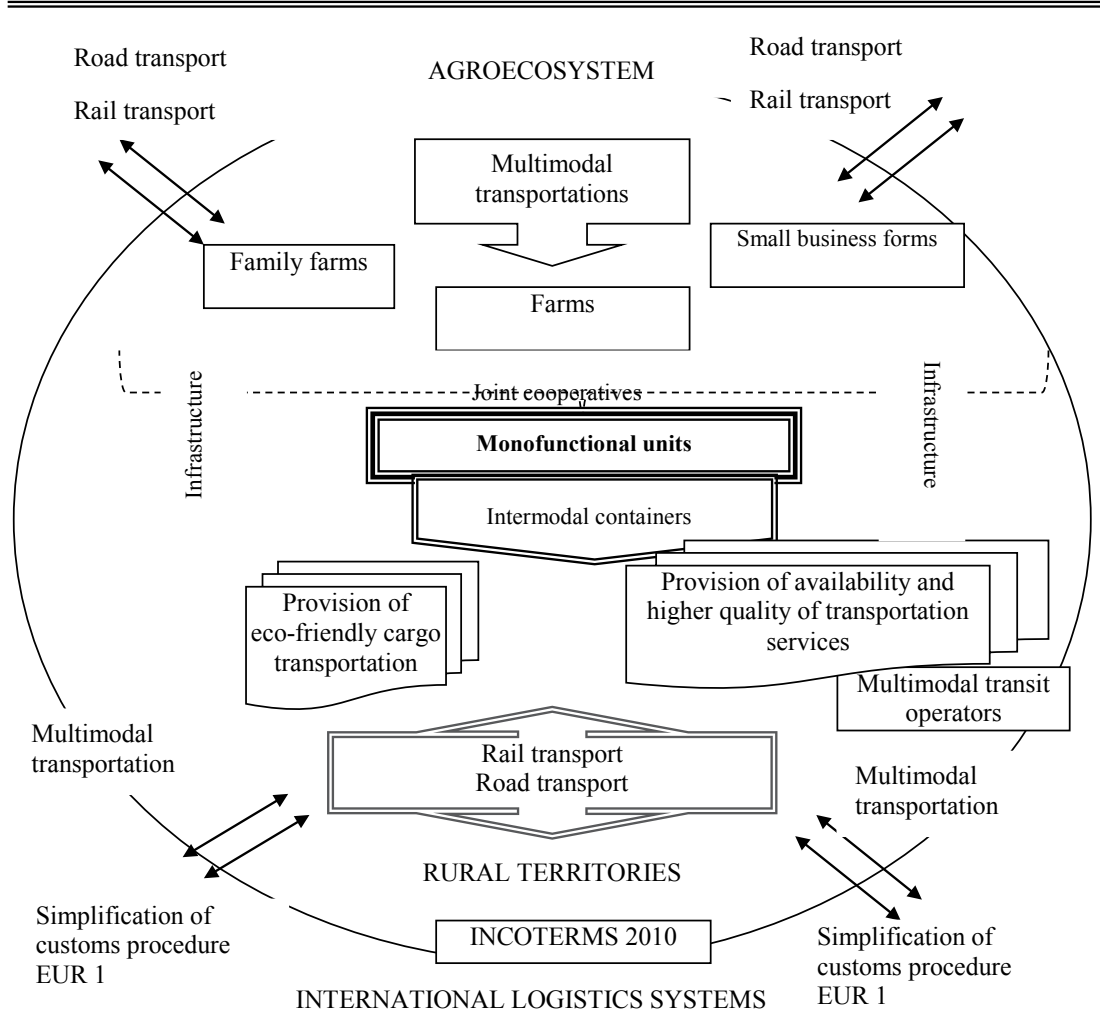

\section{Figure 2. Structural and functional scheme of the activity of monofunctional units in the rural areas}

Source: compiled by the authors

the formation of monofunctional units in the rural areas are the spatial development, convenience of the economic, market and geographical location, allocation of the material, labor and natural resources that are required by the specialized branches of the agrarian sector.

Monofunctional units are defined by the authors as territorial combinations, which may include farms, private household, family farms, in the area of distribution of dispersedly functioning transport flows and dispersed rural population. A special position in the nodes is occupied by the population, which is the main consumer of products and the main 
factor of their functioning. Adaptation of nodes to rural areas facilitates the achievement of a high non-transport effect for improving the storage of goods. A high non-transport effect is achieved by increasing the safety of cargoes, their delivery is significantly accelerated, and competitiveness and environmental friendliness of the transported products are increased. Intermodal transportation in containers will allow agricultural producers to reduce costs and delivery terms. It will also mitigate the adverse effects of excessive low-quality motor transport, i.e. traffic jams congestion, harmful emissions, deterioration of the road condition, and acci-dents.

\section{Conclusion}

Therefore, the activity of the agrarian market, which is based on the principles of logistics, promotes integration processes, adaptation to the requirements of the EU CAP and ensures economic mobility, flexibility and sustainability (stability) under conditions of the economic crises. The stability of the international logistics system is provided by a broad regional basis as a linking element between the economy of the regions, small business forms and end users. Insufficient development of modern transport and logistics technologies, multimodal transport systems and powerful multimodal transit operators restraints the lack of the extensive network of cargo customs systems and logistics centers in the area of their attraction to large transport units, significantly reduces possibilities of fulfillment of the potential of the national transport system, reduces its competitiveness compared to the countries of the Eastern Europe and the Baltic States that are more developed in this field. Subsequent research of processes of adaptation of shallow agricultural producers to the international logistic systems is related to the study of specific of going into the markets of producers of organic products and nichevuh cultures.

\section{References:}

1. Caixeta-Filho J.V. (2003). Transportation and logistics in Brazilian agriculture. Agricultural Outlook Forum. Retrieved from: http://www.ageconsearch.umn.edu/ bitstream/33141/1/fo03ca01.pdf (accessed 10 January 2019).

2. Fedoruk E. (2016). Mekhanizmy antykryzovoho upravlinnia rozvytkom lohistyky ahropromyslovoho kompleksu Ukrainy [The mechanisms of crisis management in logistics development of the agro-industrial complex of Ukraine]. Public administration and local government, vol. 1, no. 28, pp. 110-118.

3. Fihun N.V., Biloshevska O.B. (2014). Indeks efektyvnosti lohistyky (LPI) yak pokaznyk konkurentospromozhnosti ta potentsialu krayiny [The Logistics 


\section{Chapter «Economic sciences»}

Efficiency Index as a measure of competitiveness and potential of the country]. Scientific works DonNTU. Series: Economic, no. 4, pp. 223-229.

4. Hutorov O.I., Prozorova N.V., Prozorov R.G. (2013). Formuvannja loghistychnykh system v siljsjkomu ghospodarstvi: monoghrafija [Formation of logistics systems in agriculture: monograph]. Kharkiv: Kharkiv National Agrarian University V.V. Dokuchaev. (in Ukrainian)

5. Khvyschun N.V. (2016). Lohistychnyi potentsial rehioniv zakhidnoi Ukrainy [Logistic potential of Ukraine's western regions]. Regional administration and local governmen, no. 2(50), pp. 1-6.

6. Li J., Gao H., Liu Y. (2017). Requirement analysis for the one-stop logistics management of fresh agricultural products. Journal of Physics: Conference Series, vol. 887, no. 1. Retrieved from: http://www.iopscience.iop.org/article/ 10.1088/1742-6596/887/1/ 012004/pdf (accessed 20 December 2018).

7. Luo S., Xuan H. (2016). The Discussion about International Agricultural Logistics and Distribution System of Henan Wanbang. MATEC Web of Conferences 100. Retrieved from: https://www.matec-conferences.org/articles/matecconf/pdf/ 2017/14/matecconfgcm2017/031.pdf (accessed 6 December 2018).

8. Malysh S. (2016). Ukrajinsjka zernova loghistyka: potochnyj stan ta perspektyvy rozvytku okremykh seghmentiv transportnoji sfery [Ukrainian grain logistics: current state and prospects of development of separate segments of the transport sphere]. Proposition, vol. 10, pp. 22-27.

9. Maslak O. (2016). Lohistyka eksportu zerna v Ukraini [Logistics of grain exports in Ukraine]. Proposition, vol. 11, pp. 44-47.

10. Molnar O.S., Paliychuk E.S., Kovtyuk Y.I. (2017). Metodolohiia vyznachennia lohistychnoi efektyvnosti [Methodology for determining logistic efficiency]. Investments: practice and experience, vol. 19, pp. 34-37.

11. Shmatok O. (2014). Perspektyvy integhraciji ukrajinsjkoji aghrarnoji loghistyky u mizhnarodnu torghovu loghistyku. [Prospects of integration of Ukrainian agrarian logistics into international trade logistics]. Geography and Tourism: Scientific Collection, vol. 27, pp. 237-242.

12. State Statistics Committee, (2017). Transport [Transportation]. Retrieved from: http://www.ukrstat.gov.ua (accessed 16 January 2019).

13. The Cabinet of Minister of Ukraine, (2010). Pro skhvalennia Transportnoi stratehii Ukrainy na period do 2020 roku [On approving the Transport strategy of Ukraine for the period up to 2020]. Official Bulletin of Ukraine. Vol. 92.

14. The Cabinet of Minister of Ukraine (2013). Pro skhvalennia Stratehii rozvytku ahrarnoho sektoru ekonomiky na period do 2020 roku [On approval of the Strategy for the development of the agrarian sector of the economy for the period until 2020]. Official Bulletin of Ukraine. Vol. 83.

15. The Cabinet of Minister of Ukraine (2017). Pro skhvalennia Koncepciii rozvytku fermersjkykh ghospodarstv ta siljsjkoghospodarsjkoji kooperaciji na 2018-2020 roky [On approval of the Concept for the development of farms and agricultural cooperatives for 2018-2020]. Official Bulletin of Ukraine. Vol. 79.

16. The World Logistics Performance Index Indicators. Retrieved from: http://www.info.worldbank.org (accessed 26 December 2018). 
17. Volnova O. (2010). Lohistychnyi pidkhid do formuvannia ahrarnoho vyrobnytstva [Logistic approach to the formation of agrarian production]. Herald of Khmelnytskyi national university, vol. 2, no. 1, pp. 161-164.

18. Vorotnikov I., Kolotyrin K., Vlasova O., Petrov K. (2017). Optimization of agricultural products storage and marketing on the basis of logistics. Revista ESPACIOS, vol. 38, no. 49, 24 p.

19. Yefanov V.A. (2016). Osoblyvosti lohistyky v suchasnomu silskomu hospodarstvi Ukrainy. [Peculiarities of logistics in the modern agricultural holding of Ukraine]. Visnyk KhNUU. Series: Economic Sciences, vol. 1, pp. 94-99.

20. Yingxia Z., Xiangyu G. (2015). The Research on Chinese Agricultural Product Logistics Based on the Supply Chain. Retrieved from: https://www.agriskmanagementforum.org/sites/agriskmanagementforum.org/files/ Documents/12651774740z0nfa8s.pdf (accessed 16 January 2019). 